\title{
Influence of the Mother Bulb Size on the Growth and Development of Allium 'Purple Rain'
}

\author{
Aurelia Elena ROȘCA ${ }^{1 *}$, Lucia DRAGHIA ${ }^{1}$, Liliana Elena CHELARIU ${ }^{1}$, Maria BRÎNZĂ ${ }^{1}$ \\ ${ }^{1}$ University of Agricultural Sciences and Veterinary Medicine Iasi, Romania \\ *)Corresponding author, e-mail: aureliaelena.rosca@gmail.com
}

BulletinUASVM Horticulture 73(2) / 2016

Print ISSN 1843-5254, Electronic ISSN 1843-5394

DOI:10.15835/buasvmcn-hort:12253

\begin{abstract}
The experiment aim was to study the influences of the mother bulb weight on the growth and development, of the plants of ornamental onion. The study was conducted during October 2015 - June 2016 and the biologic material was represented by Allium 'Purple Rain'. The bulbs were divided in three different weight groups: $\mathrm{W}_{1}$ (15.1-30 g), $\mathrm{W}_{2}(5.1-15 \mathrm{~g}), \mathrm{W}_{3}(<5 \mathrm{~g})$, which reprezented the three variants $\left(\mathrm{V}_{1}, \mathrm{~V}_{2}\right.$, respectively $\left.\mathrm{V}_{3}\right)$. The bulbs were planted in the field and the plants were studied thru biometric determinations. The results were compared with the average of the experiment. The research showed that the analyzed characters (number and length of leaves, number and weight of new formed bulbs, flowers yield, diameter of the inflorescence) were decreasing from $V_{1}$ to $V_{3}$ variant. The highest number of the flowering plants $(98.9 \%)$ resulted from $V_{1}$ variant. From $V_{2}$, bloomed only $20 \%$ of the bulbs and from $V_{3}$ the bulbs have not flourished. The first flowers were obteined from the plants resulted from the biggest bulbs $\left(\mathrm{V}_{1}\right)$, while the plants from $\mathrm{V}_{2}$ flourished with arround 3 days later and the plants from $V_{3}$ florished with around 7 days later. The capacity to form new bulbs, expressed in bulb number or bulb weight per plant, was increased with the increasing of the mother bulb weight. The number of leaves per plant and the length of the leaves were higher for $V_{1}$, compared the other two variants.
\end{abstract}

Keywords: Allium, bulb weight, plant development

\section{INTRODUCTION}

Allium is one of the biggest, various, popular and wide-spread plant gender in the world. For a long time the Alliums were known mostly as vegetables but in the last decades the Allium ornamental species became more and more popular like garden plant (Fritsch and Friesen, 2002). Their plants have a very long decorative period, from spring to late summer or even fall, offering various species and cultivars. Because of the high resistance to environmental conditions and so various color range, the interest for the Allium cut flowers have been increased in last period (Szot et al., 2009).

In the present, from a commercial point of view, there is a great interest for the ornamental Allium species and cultivars, in the flower markets all over the world. From the first Alliums, cultivated like ornamental, it can be counted $A$. giganteum, $A$. moly, A. sphaerocephalon (Davies, 1992; Harding, 2004; Kamenetsky and Fritsch, 2002).
Davies (1992), talks about very few buffs of ornamental Alliums, that has not a good reputation for such a great and various plant gender. Thus it became very needful to carry out in the establishment of a cultivation technology, adapted to wide areas, where these plants can be grown.

In Romania there are wildly growing many Allium species with important ornamental qualities (A. paniculatum L., A. ursinum L., $A$. saxatile M. Bieb., A. atroviolaceum Boiss), some of them are already presents in the ornamental plants catalogs of the great markets.

Regarding these valuable species, in the last years, various studies have been conducted, in Romania. Draghia etal. (2010) carried outresearches on some species of wild flora from the north-east of Romania, including Allium ursinum L., in order to assess the adaptation capabilityand the possibility of introducing them in culture as ornamentals. Mitroi (2012), conducted a study in order to evaluate the variability of decorative morphological characters 
of Allium atroviolaceum, species from the romanian wild flora. Zaharia (2014) emphasizes the possibility of cultivating Allium paniculatum L. species and its technological scheme.

Concerning the adaptability of some ornamental Allium species from the wild flora, it is very important to improve and establish the growing schemes for these plants, in the Romanian area. Regarding the growing technology, very important is the quality of the planting material. So, the aims of this study is to evaluate the importance of the bulb weight, for the plant growth and ornamental characters development, for the Allium 'Purple Rain' cultivar, obtained from the famous Allium hollandicum (Frish, 2015). The importance of the bulb size was shown by various studies. Mosleh (2008), shown that the mother bulb size of edible onions, can increase the bulbs and seeds yield and Laskowsca et al. (2013) shown that the size of Allium moly bulbs increased the flowers quality and the bulbs yield.

\section{MATERIALS AND METHODS}

The experiment was conducted in the experimental field of Floriculture discipline, from University of Agricultural Sciences and Veterinary Medicine of Iași, Romania, in the period October 2015 - July 2016. The soil properties of the top $250 \mathrm{~mm}$ were determined just before planting. Analytical results indicated: $\mathrm{pH} 7,8$, humus content $4.2 \%, 3 \%$ carbonates, $29.5 \%$ cation exchange capacity, $1.08 \mathrm{me} / 100 \mathrm{~g}$ complex Na. Values of elements registered were: 0.22 total $\mathrm{N}$, $246 \mathrm{ppm}$ accessible $\mathrm{P}$ and $429 \mathrm{ppm}$ accessible $\mathrm{K}$. Zinc, copper, boron, mangan were $15 \mathrm{ppm}$, 5,0 ppm, 0,32 ppm and 51 ppm respectively.

The material was represented by a cultivar of ornamental onion Allium 'Purple Rain' whose bulbs were planted in field (outside). This is decorative thru its deep purple, star shaped flowers, grouped in simple spherical umbels. The leaves are wide, grown around the stem base. The stem can grow to about $60-80 \mathrm{~cm}$ height. The plants form every year new bulbs, wich can be separated and replanted. This ornamental onion, blossoms betwen april and june (Fig. 1).

The bulbs were divided in three weight groups (Tab. 1) and before planting, they were disinfected in Kaptan (1\%) and Topsin (0.7\%) solutions.

The bulbs were planted in 20 October 2015 and during the frosty season the plots was mulched with hay and straw. The experiment was organized in randomized blocs design, with three replications. A plot has a surface of $3.00 \mathrm{~m}^{2}$ and it was planted with 30 bulbs. Observations and determinations were made by measurements on the main morpho-decorative characteristics of $A$. 'Purple Rain' cultivar (number of leaves, leaves length, inflorescence diameter,number of flowering plants, number of bulbs per plant and bulbs weight per plant). To obtain the number of bulbs per plant and bulbs weight, the bulbs were harvested, cleaned up, weighing and counted.

The experimental data was processed using analysis of variance, which established limits of probability for each weight group of bulbs, compared with the control (average of experiment for each character). The significance of the differences was assessed by taking into account the LSD test (Săulescu and Săulescu, 1967).

\section{RESULTS AND DISCUSSION}

The biometric measurements and the analysed data, shown that the number of leaves was considerable higher at the plants obtained from the $\mathrm{W}_{1}$ bulbs group (15.1-30 g), respectively $\mathrm{V}_{1}$, and the differences toward the control (average of the experiment) were distinctly significant positive, with a difference of 1.19 lives more than the control (Tab. 2). The $\mathrm{V}_{2}$ (5.1 - $15 \mathrm{~g}$ ) registred an average value very close to the control, being not statistically insured. The plants from $\mathrm{V}_{3}$ formed a lower number of leaves (4.42) and the difference toward the control was distinctly significant negative (Tab. 2).

The length of leaves was also different between the variants, thus from the $V_{1}$ the plants developed $55.07 \mathrm{~cm}$ long leaves, with $10.52 \mathrm{~cm}$ more than the control (the experience average), being statistically insured. From the $W_{2}$ bulbs group $\left(V_{2}\right)$, the plants reached $44.11 \mathrm{~cm}$ long leaves, less than variant $\mathrm{V}_{1}$ but not statistically insured because of the closeness to the control. The plants of $\mathrm{V}_{3}$ variant were noted with the shortest leaves $(34.48 \mathrm{~cm})$, with a difference of $10.07 \mathrm{~cm}$ toward the control, registering significant differences lower then the average experience (control) (Tab.3).

The same decrease trend from the $V_{1}$ to $V_{3}$ was observed also concerning new formed bulbs, studied individualy for each plants from the three weight groups. At the $V_{1}$ variant, the new bulbs obtained from every plant have an average 


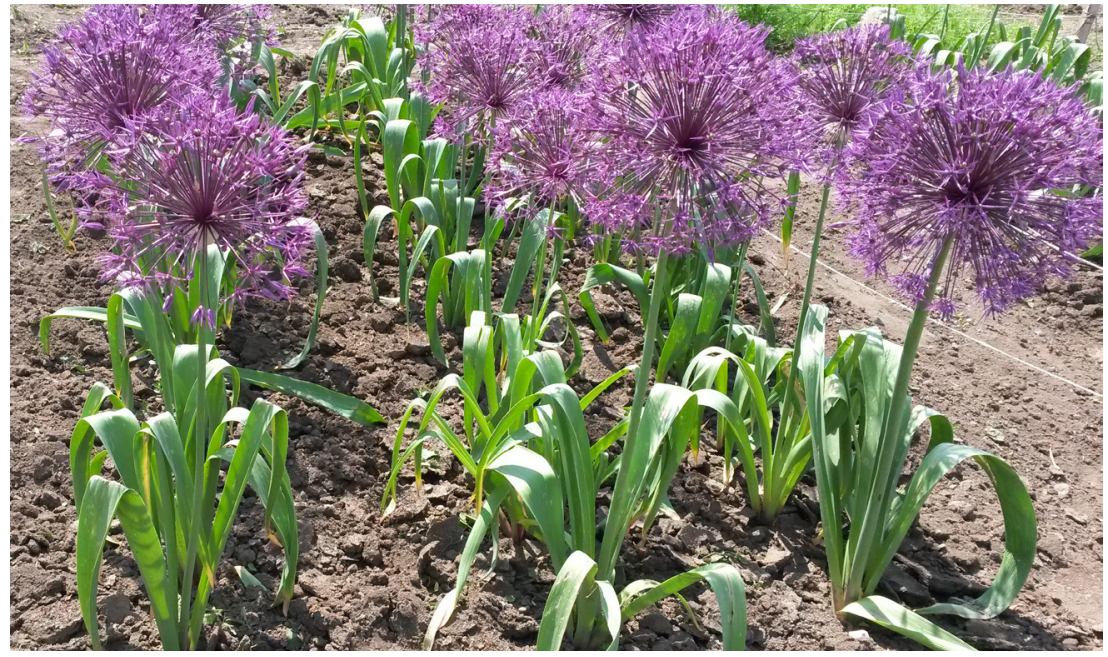

Fig. 1. Allium 'Purple Rain' - general aspect (original photo)

Tab. 1. Experimental variants (weight groups)

\begin{tabular}{ccc}
\hline Weight groups & Variants & Specification/Graduations \\
\hline $\mathrm{W}_{1}$ & $\mathrm{~V}_{1}$ & $15.1-30 \mathrm{~g}$ \\
\hline $\mathrm{W}_{2}$ & $\mathrm{~V}_{2}$ & $5.1-15 \mathrm{~g}$ \\
\hline $\mathrm{W}_{3}$ & $\mathrm{~V}_{3}$ & $<5 \mathrm{~g}$ \\
\hline
\end{tabular}

weight of $135.74 \mathrm{~g}$, that was a positive distinctly significant result, compared with the control. From the $V_{2}$, every plant developed $86.97 \mathrm{~g}$ of new bulbs, not statistically insured but better than $V_{3}$, where were obtained $43.60 \mathrm{~g}$ bulbs/plants, which ensures negative distinct significant differences (Tab. 4).

The daughter bulbs number per plant, also oscillated between the variants. The most valuable result was registered by the plants from the $\mathrm{W}_{1}$ group ( $\mathrm{V}_{1}$ variant), 6.33 bulbs per plant, with $29.7 \%$ more than the experiment average and positive significant differences. From the other two weight groups, the results were not statistically insured, their values being close to those of the control (Tab.5).

The period of blooming, capacity blooming (total number of inflorescences/variant) and the inflorescences size (diameter) are very important characters regarding the decorative effect of Allium.

The Allium 'Purple Rain'cultivar, in the year 2016, blossomed between April 20 and May 1 . Analyzing the data on earliness of flowering, it has been observed that the earliest are the plants resulted from the biggest bulbs $\left(V_{1}\right)$, with around
3 days earlier than $V_{2}$ and 7 days earlier than $V_{3}$ (fig. 2).

The different mother bulb weight, between the variants, influenced also the anthesis process, like inflorescence development, in this case diameter (cm) and number of flowering plants. The flowering capacity is the most important character that can establish the quality of the ornamental plants and becomes the most important propose in the process of the cultivation technology establishment.

The number of flowering plants, calculated from the total plants per variant, was considerably different betwen the variants. In the first group $\left(V_{1}\right), 29.67$ of the plants $(98.9 \%)$ formed flowers and the difference compared to the control was very significant positive (17.67 flowers) (Tab. 6). In the second group $\left(\mathrm{V}_{2}\right)$, only $20 \%$ of the plants formed flowers, and the result was negative distinct significant. From the third weight group, only $1.1 \%$ plants formed flowers, but it could not get to the maturity. The result in this case, was very significant negative.

The collected data shown that, the mother bulb weight influenced the inflorescence diameter, expressed in centimetres, more for the $\mathrm{V}_{1}$, were the 
Tab. 2. The influence of the bulb weight on the number of leaves

\begin{tabular}{ccccc}
\hline \multirow{2}{*}{ Variants } & \multicolumn{2}{c}{ Number of leaves/plant } & d ( \pm ) & $\begin{array}{c}\text { Significance of } \\
\text { differences }\end{array}$ \\
\cline { 2 - 4 } & Absolute value & Relative value (\%) & & ** \\
\hline $\mathrm{V}_{1}$ & 6.64 & 121.7 & -0.15 & ns \\
\hline $\mathrm{V}_{2}$ & 5.31 & 97.3 & -1.04 & 00 \\
\hline $\mathrm{V}_{3}$ & 4.42 & 81.0 & - & - \\
\hline Average (control) & $\mathbf{5 . 4 5}$ & $\mathbf{1 0 0 . 0}$ & & 0 \\
\hline
\end{tabular}

LSD 5\% $=0.59$

LSD $1 \%=0.97$

LSD $0,1 \%=1.82$

Tab. 3. The influence of the bulb weight on the leaves length

\begin{tabular}{|c|c|c|c|c|}
\hline \multirow[b]{2}{*}{ Variants } & \multicolumn{2}{|c|}{ Leaves length $(\mathrm{cm})$} & \multirow[b]{2}{*}{$\mathrm{d}( \pm \mathrm{cm})$} & \multirow{2}{*}{$\begin{array}{l}\text { Significance of } \\
\text { differences }\end{array}$} \\
\hline & $\begin{array}{l}\text { Absolute value } \\
(\mathrm{cm})\end{array}$ & Relative value (\%) & & \\
\hline $\mathrm{V}_{1}$ & 55.07 & 123.6 & 10.52 & $*$ \\
\hline $\mathrm{V}_{2}$ & 44.11 & 99.0 & -0.45 & ns \\
\hline $\mathrm{V}_{3}$ & 34.48 & 77.4 & -10.07 & 0 \\
\hline Average (control) & 44.55 & 100.0 & - & - \\
\hline
\end{tabular}

LSD $1 \%=11.20$

LSD $0,1 \%=20.96$

Tab. 4. The influence of the mother bulb weight on the weight of new bulbs formed/plant

\begin{tabular}{|c|c|c|c|c|}
\hline \multirow[b]{2}{*}{ Variants } & \multicolumn{2}{|c|}{ Bulb weight (g) } & \multirow[b]{2}{*}{$d( \pm g)$} & \multirow{2}{*}{$\begin{array}{l}\text { Significance of } \\
\text { differences }\end{array}$} \\
\hline & $\begin{array}{c}\text { Absolute value } \\
\text { (g) }\end{array}$ & Relative value (\%) & & \\
\hline $\mathrm{V}_{1}$ & 135.74 & 152.9 & 46.97 & $* *$ \\
\hline $\mathrm{V}_{2}$ & 86.97 & 98.0 & -1.80 & ns \\
\hline $\mathrm{V}_{3}$ & 43.60 & 49.1 & -45.17 & oo \\
\hline Average (control) & 88.77 & 100.0 & - & - \\
\hline
\end{tabular}

LSD $1 \%=26.78$

LSD $0,1 \%=50.12$

spherical umbels achived, $22.73 \mathrm{~cm}$ in diameter, very significantly positive differences compared to the control.

The quality of the flowers depends not only on the uniformity of flowering, but also, on the development of the flowers and inflorescences. In this sense, beside of the flowers yield, the inflorescence diameter, at the maturity of flowers, was studied. This character was observed only at the flowering plants (Tab. 7).

The plants of $\mathrm{V}_{2}$ variant have formed umbels with $18.57 \mathrm{~cm}$ in diameter (lower than control $11.1 \%$ ) and the result was significantly negative.
Regarding the third variant $\left(\mathrm{V}_{3}\right)$, the diameter value was 0 , because the flower formed in this variant did not reached the maturuty and died at the bud stage (Tab. 7).

Similar influences regarding the mother bulb size on the flowering earliness, flowering plants number, inflorescence diameter and new bulbs yeld were described by Laskovska et al. (2013), at the Allium moly L. cultivar.

\section{CONCLUSIONS}

The mother bulb weight of ornamental onion (Allium 'Purple Rain') influences the plant growth 
Tab. 5. The influence of the mother bulb weight on the number of new bulbs formed/plant

\begin{tabular}{|c|c|c|c|c|}
\hline \multirow{2}{*}{ Variants } & \multicolumn{2}{|c|}{ Number bulbs/plant } & \multirow{2}{*}{$d( \pm)$} & \multirow{2}{*}{$\begin{array}{c}\text { Significance of } \\
\text { differences }\end{array}$} \\
\hline & Absolute value & Relative value (\%) & & \\
\hline $\mathrm{V}_{1}$ & 6.33 & 129.7 & 1.45 & $*$ \\
\hline $\mathrm{V}_{2}$ & 4.55 & 93.3 & -0.33 & ns \\
\hline $\mathrm{V}_{3}$ & 3.75 & 76.9 & -1.13 & ns \\
\hline Average (control) & 4.88 & 100.0 & - & - \\
\hline
\end{tabular}

LSD $5 \%=1.21$

LSD $1 \%=2.01$

LSD $0,1 \%=3.76$

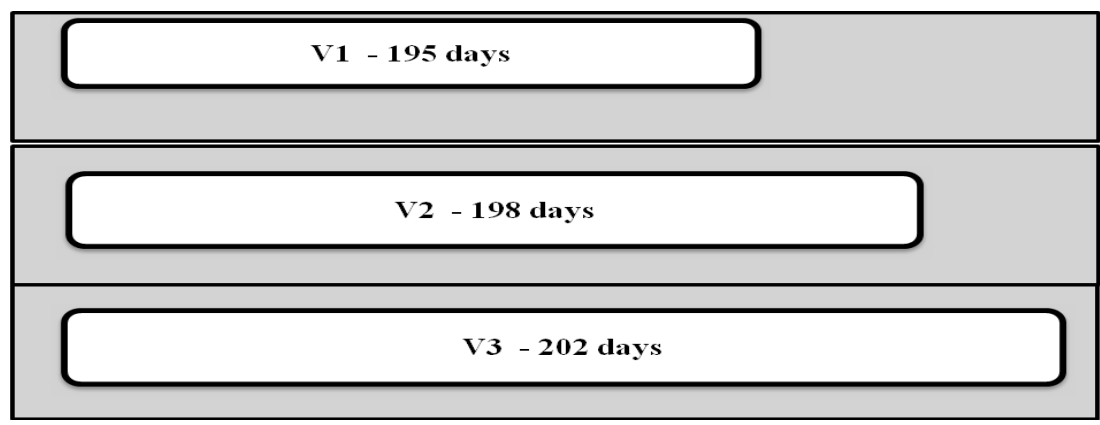

Fig. 2. Duration (number of days) from planting to flowering

Tab. 6. The influence of the weight bulb on the inflorescences number

\begin{tabular}{|c|c|c|c|c|}
\hline \multirow{2}{*}{ Variants } & \multicolumn{2}{|c|}{ Inflorescences (total number) } & \multirow{2}{*}{$d( \pm)$} & \multirow{2}{*}{$\begin{array}{c}\text { Significance of } \\
\text { differences }\end{array}$} \\
\hline & Absolute value & Relative value (\%) & & \\
\hline $\mathrm{V}_{1}$ & 29.67 & 247.2 & 17.67 & $* * *$ \\
\hline $\mathrm{V}_{2}$ & 6.00 & 50.0 & -6.00 & oo \\
\hline $\mathrm{V}_{3}$ & 0.33 & 2.8 & -11.67 & ooo \\
\hline Average (control) & 12.0 & 100.0 & - & - \\
\hline
\end{tabular}

\section{LSD 5\% $=2.93$}

LSD $1 \%=4.85$

LSD $0,1 \%=9.08$

Tab. 7. The influence of the bulb weight on the inflorescence diameter

\begin{tabular}{|c|c|c|c|c|}
\hline \multirow{2}{*}{ Variants } & \multicolumn{2}{|c|}{ Inflorescences diameter $(\mathrm{cm})$} & \multirow{2}{*}{$\mathrm{d}( \pm \mathrm{cm})$} & \multirow{2}{*}{$\begin{array}{c}\text { Significance of } \\
\text { differences }\end{array}$} \\
\hline & Absolute value & Relative value (\%) & & \\
\hline $\mathrm{V}$ & 22.73 & 165.1 & 8.97 & $* * *$ \\
\hline $\mathrm{V}_{2}$ & 18.57 & 134.9 & 4.80 & $* * *$ \\
\hline $\mathrm{V}^{2}$ & 0.0 & 0.0 & -13.77 & 000 \\
\hline Average (control) & 13.77 & 100.0 & - & - \\
\hline
\end{tabular}

LSD $1 \%=1.41$

LSD $0,1 \%=2.65$

and development. In case of all the analyzed characters (number and length of leaves, number and weight of new bulbs formed, flowers yield, diameter of the inflorescence) the best results were obtained at the variant $V_{1}$ from which were used the biggest bulbs ( $\mathrm{W}_{1}$ group) and the decreasing trend of the results was from $V_{1}$ to $V_{3}$. Compared with the average of the experiment (control), at variants $V_{1}$ and $V_{3}$ were registered positive, respectively negative differences, both 
in the number of leaves (distinct differences) and leaves lenght (significant differences). The $\mathrm{V}_{2}$ variant registered insignificant differences. The number of flowering plants, was 29.67 for $V_{1}$ (very significant positive differences), 6.00 for $\mathrm{V}_{2}$ (distinct significant positive differences) and 0.33 in case of $\mathrm{V}_{3}$ (very significant negative differences); the inflorescences diameter, was 22,73 for $V_{1}$ and 18.57 for $\mathrm{V}_{2}$ variants. Regarding the bulbs yield, in $\mathrm{V}_{1}$ the number of bulbs/plants was 6.33, 4.55 in $\mathrm{V}_{2}$ and 3.75 in $\mathrm{V}_{3}$, (differences statisticaly assured only in $V_{1}$ ). The weight of new bulbs was $135.74 \mathrm{~g}$ for $\mathrm{V}_{1}, 86.97 \mathrm{~g}$ for $\mathrm{V}_{2}$ and $43.60 \mathrm{~g}$ for $\mathrm{V}_{3}$. To obtain plants of Allium 'Purple Rain' with high decorative value, the results can recommend using big bulbs, weighing more than $15 \mathrm{~g}$.

\section{REFERENCES}

1. Davies D (1992). Alliums, the ornamental onions. B. T. Batsford, London: 12-15.

2. Draghia L, Chelariu EL, Sîrbu C (2010). The behaviour in crop of some species with ornamental features from spontaneous flora of Romania. Lucrări Științifice USAMV Iaşi, Seria Horticultură, Nr 53, Vol. 2 : 259-264.

3. Fritsch RM, Friesen N (2002). Chapter 1: Evolution, Domestication, and Taxonomy. In H.D. Rabinowitch and L. Currah, eds. Allium Crop Science: Recent Advances. Wallingford, UK: CABI Publishing.: 5-30.

4. Fritsch RM (2015). Checklist of ornamental Allium species and cultivars currently offered in the trade. LeibnizInstitut für Pflanzengenetik und Kulturpflanzenforschung Gatersleben, Germany: 1,2,17,24,27,31,32,50,56,63.
5. Harding S (2004). Inflorescence Development in Allium ampeloprasum var. Babingtonii (Babington's Leek). Cardiff University, School of bioscience, UK: 5-66.

6. Laskowska H, Pogroszewska H, Durlak W, Kozak D (2013). The effect of bulb size and application method of asahi biostimulatoron the growth and yield of Allium moly L. Acta Agrobotanica, Vol. 66 (1): 89-94.

7. Kamenetsky R, Fritsch RM (2002). Ornamental Alliums. In: H. D.Rabinowitch and L. Currah (eds.) Allium crop science: recent advances. CAB Int.,Wallington, UK.: 459-492.

8. Mitroi D, Nicu C, Mandea M (2012). Variability of decorative morphological characteristics in the species Allium atroviolaceum boiss. of spontaneous vegetation. South Western Journal of Horticulture, Biology and Environment P-Issn: 2067- 9874, E-Issn: 2068-7958 Vol.3 , No.2:131-144.

9. Mosleh UD (2008). Effect of mother bulb size and planting time on growth, bulb and seed yield of onion. Bangladesh J. Agril. Res. 33(3): 531-537.

10. Săulescu NA, Săulescu NN (1967). Câmpul de experiență. Editura Agro-Silvică, București.

11. Szot P, Pogroszewska E, Laskowska H, Durlak W (2009). Quality and mechanical properties of inflorescence shoots of selected species of ornamental garlic as dependent on cultivation measures. Annals of Warsaw University of Life Sciences - SGGWHorticulture and Landscape Architecture 30: 67-77.

12. Zaharia A (2014). Study of value ornamental species of spontaneous flora of Romania and the possibility of introducing them in the culture. PhD thesis, University of the Agriculture Sciences and Veterinary Medicine „Ion Ionescu de la Brad" Iași. 